\title{
Magnetic Susceptibility and Natural Gamma Radioactivity as Indirect Indicators of Impurities in Limestones of the Sabinas Basin: Possible Relationships with the Sedimentation Environment
}

\author{
José A. Batista Rodríguez¹, Joaquín A. Proenza Fernández², Gloria I. Dávila Pulido, \\ Mitzué Garza García1, Itzayana Y. Zamora Medellín' ${ }^{1}$ \\ ${ }^{1}$ Universidad Autónoma de Coahuila, Escuela Superior de Ingeniería, Coahuila, México \\ ${ }^{2}$ Departament de Cristallografia, Mineralogia i Dipòsits Minerals, Facultat de Geologia, Universitat de Barcelona, Barcelona, Spain \\ Email: josebatista@uadec.edu.mx
}

How to cite this paper: Rodríguez, J.A.B., Fernández, J.A.P., Pulido, G.I.D., García, M.G. and Medellín, I.Y.Z. (2017) Magnetic Susceptibility and Natural Gamma Radioactivity as Indirect Indicators of Impurities in Limestones of the Sabinas Basin: Possible Relationships with the Sedimentation Environment. Journal of Geoscience and Environment Protection, 5, 77-91.

https://doi.org/10.4236/gep.2017.510007

Received: August 29, 2017

Accepted: October 16, 2017

Published: October 19, 2017

Copyright (๑) 2017 by authors and Scientific Research Publishing Inc. This work is licensed under the Creative Commons Attribution International License (CC BY 4.0).

http://creativecommons.org/licenses/by/4.0/

\begin{abstract}
This study presents an analysis of magnetic susceptibility and natural gamma radioactivity as indirect indicators of impurities in Cretaceous limestones of the Sabinas basin, as well as of the possible relation of these physical properties with the changes in the sedimentation environment. Both of these physical properties indicate changes in the degree of impurities and the mineralogical composition of this rock, principally in its organic matter and detritus content. Considering that the sedimentation environment determines the impurities in these rocks, possible environmental conditions at different levels of the Cretaceous were suggested using the magnetic susceptibility, total gamma radiation and potassium values, as well as the uranium and thorium concentration in the limestones. The analyses suggest variations in the depth of water table of the basin, which are mainly related to transgressions and marine regressions.
\end{abstract}

\section{Keywords}

Magnetic Susceptibility, Natural Gamma Radioactivity, Limestones, Environment Sedimentation, Sabinas Basin

\section{Introduction}

There are various geological structures found in northeast Mexico, which show 
the features of the geological evolution in the region since the late Paleozoic. The Sabinas Basin, an area with significant mineral resources, is one of these structures. Significant accumulations of metallic and non-metallic ores and hydrocarbons are associated with the rocks that fill this basin [1] [2] [3] [4] [5].

Several geological, geophysical and geochemical surveys have been carried out in this basin with the main objective of prospecting and exploring its mineral deposits [1]-[6]. Despite the number of surveys performed, the origin and evolution conditions of some levels of sedimentary rocks remain unknown.

Several previous studies have used magnetic susceptibility $(\kappa)$ and natural gamma radioactivity (NGR) to assess impurities in limestone and paleoenvironmental change during the formation of sedimentary rocks [7]-[13].

In this context, the $\kappa$ of specific rocks is related to the proportion and texture (magnetic grain size and shape) in which magnetic minerals are present, with the most significant being iron oxides and hydroxides, iron sulfides and ferromagnesian silicates (e.g., magnetite, hematite, maghemite, pyrrhotite) [9]. These minerals may be present as accessory minerals in the sedimentary rocks [14]. In the case of carbonate rocks, such as limestone, this physical property is related to its impurities [8] [10] [11] [13].

NGR is mainly caused by the gamma radiation emitted by both the radioactive isotope $\mathrm{K}^{40}$ and radioactive isotopes of the $\mathrm{U}\left(\mathrm{U}^{238}\right.$ and $\left.\mathrm{U}^{235}\right)$ and $\mathrm{Th}^{232}$ series [7]. Therefore, the NGR is expressed in concentrations of K (\%), U (ppm) and Th (ppm). Most potassium is found in rocks that form silicate minerals such as feldspars and micas, as well as some other common K-bearing minerals such as alunite and glauconite [15]. Th and $U$ are constituents of accessory minerals, such as zircon, monazite, allanite, xenotime, apatite and sphene, as well as some minerals that have Th and $\mathrm{U}$ as a major constituent, such as uraninite (which contains $\mathrm{U}$ ), thorite and thorianite (which contain Th), and uranothorite and uranothorianite (which contain both elements) [16]. The concentrations of U, Th and $\mathrm{K}$ can be related to the impurities in limestones [8] [11] [13]. The concentration of Th is an indicator of detrital material in limestone [11] [13] [17], while the concentration of $U$ may indicate the presence of in organic matter [18].

As carbonate sedimentary rocks predominate in the stratigraphic sequence of the Sabinas Basin, this study presents an analysis of potential magnetic susceptibility $(\kappa)$ and natural gamma radioactivity (NGR) as indirect indicators of impurities in limestones and possible relationships in the sedimentation environment of this rock sequence of the basin.

\section{Geological Setting}

Found in northeastern Mexico (Figure 1), the Sabinas Basin is over 5000 meters thick and comprises sedimentary rocks deposited in a marine environment. The basin initially developed on the margin of the North American Craton during the opening of the Gulf of Mexico in the early Mesozoic. The upper Tamaulipas (the Tamaulipas arc and Burro-Peyotes block) and Coahuila blocks are the main 


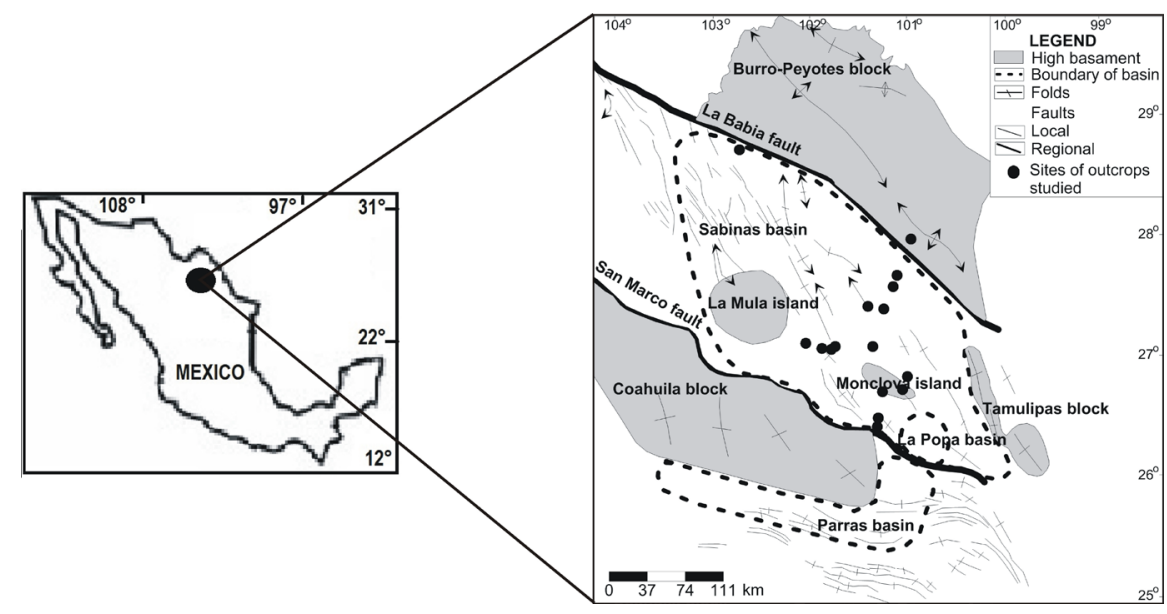

Figure 1. Location of the study area (Sabinas Basin) and the studied sites. Structural configuration and tectonic characteristics of northeastern Mexico. Modified from [19].

paleotectonic and paleogeographic limits of the basin (Figure 1), which comprises a depression formed by a series of subsided blocks and some elevations to the Northwest, which separate it from the Chihuahua basin. Small uplifted blocks of basement can be found within the Sabinas basin itself (La Mula and Monclova Island) [1].

The Sabinas Basin evolved over several evolutionary phases, the first of which being a long period of Triassic to Lower Jurassic magmatic-arc activity. A rupture of the lithosphere occurred during the second phase, while the rift that occurred with opening of the Gulf of Mexico developed in the third phase [1].

Several marine transgressions and regressions occurred in this region during most of the Mesozoic, with these latter processes, linked to the structural characteristics and tectonic evolution of the region, determining sedimentation patterns. Those patterns changed in the late Cretaceous, when the Laramide orogeny (late Cretaceous to Eocene) caused a tectonic uplift that obliterated the structure of the basin.

Three main depositional supersequences are associated with the rift, drift and foreland stages of the evolution of the Sabinas Basin (Figure 2). The first supersequence comprises a depositional cycle, which consists of conglomerates, salt interbedded with fine-grained red and green terrigenous rocks, anhydrite, and carbonates. The stratigraphic position of this first cycle suggests a period of deposition during the Callovian(?)-lower Oxfordian of the upper Jurassic [20]. The abovementioned group of rocks mostly appeared in the central part of the basin and is representative of a transgressive-regressive cycle [1].

The second supersequence represents the drift stage and comprises depositional cycles II, III and IV. Cycle II is corresponding to the upper Oxfordian-Berriasian age, while Cycle III corresponds to the Valanginian-Aptian age, and Cycle IV corresponds to the Aptian-Cenomanian age.

Carbonated units in the base of Cycle II indicate a transgressive section that degrades up to coastal terrigenous facies. Black carbonaceous shales of the La 


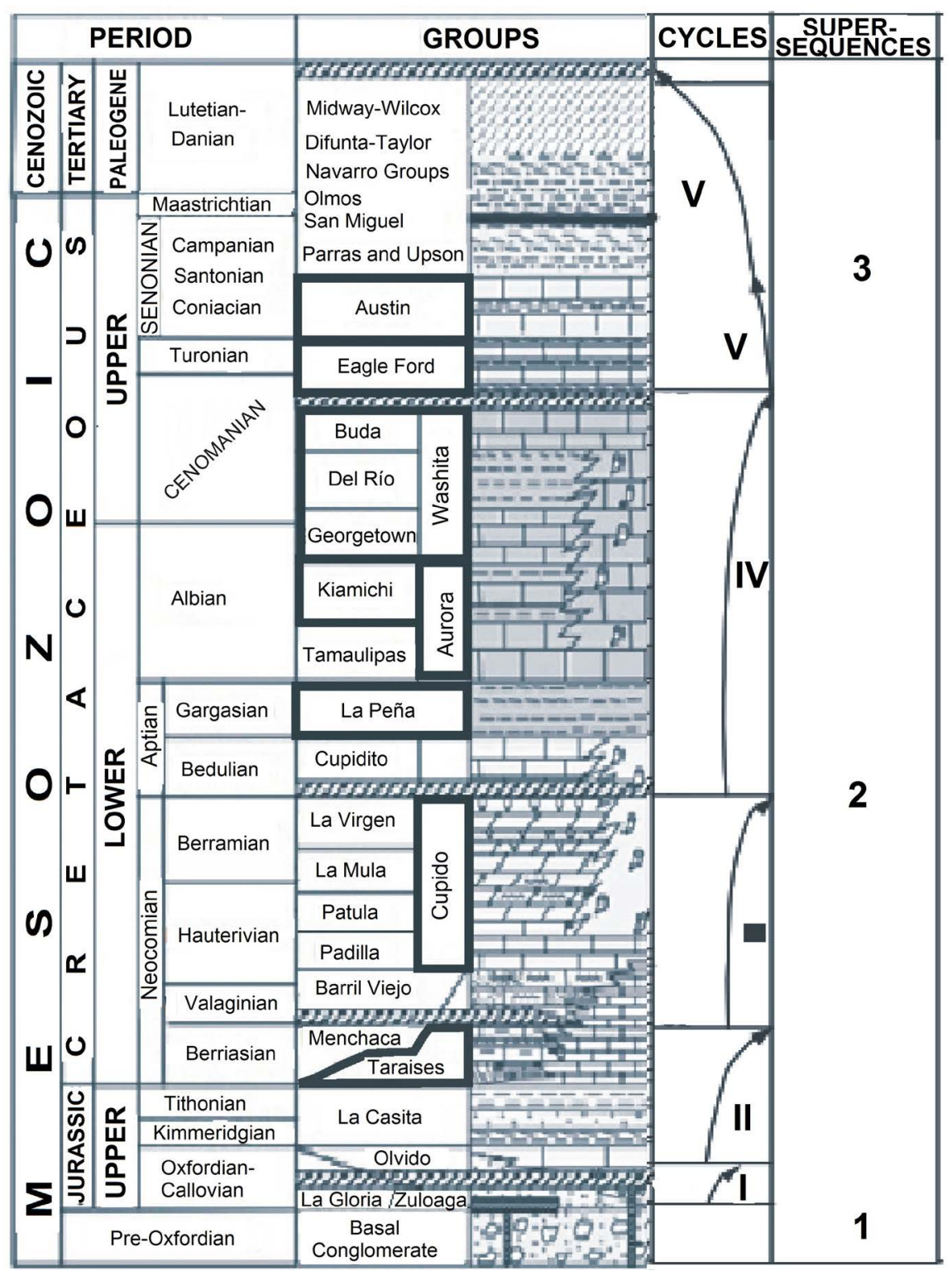

Figure 2. Generalized stratigraphic column of the Sabinas Basin and surroundings (modified from [1]). Continuous solid line indicates the geological formations studied here.

Casita Formation are found above the base, with a basal member representing a maximum flooding surface that covers a broader area than the preceding cycle that occurred in the Kimmeridgian age [21]. This formation consists of three members in the Sabinas basin, with the lower and upper members composed of shale and the middle member composed of sandstone interbedded with carbonates. The shales, carbonates and sandstones of the La Casita Formation present continuous transgression and indicate a gradual deepening of the basin. During this period, the northwestern limit of the basin was flooded and the La Mula block was surrounded by the sea.

Terrigenous and clay-rich carbonate rocks with varying grain sizes were deposited during the Berriasian age (early Cretaceous). Represented by interbed- 
ded shales and carbonates, the Taraises Formation was deposited during this pe$\operatorname{riod}[21]$.

The subsidence of the basin and the accumulation of sandstones and fine-grained terrigenous rocks continued in Cycle III. During the Hauterivian-Barremian age, a gradual change in sedimentation occurred, while the deposition of dolomite began with an increase in interbedded siltstone and reddish shales towards the emerging continental areas represented by the Coahuila and Tamaulipas blocks. The Cupido Formation, constituting a barrier reef complex that restricted the entry of seawater of normal salinity into the lagoon, was deposited during these geological periods [22]. This geological formation was deposited as a prograding system during a sea-level highstand.

Later, a new transgressive system began (Cycle IV) in which the basal high-energy carbonates transitioned upward into low-energy carbonates, with these rocks now known as the Cupidito Limestone [23].

The continuation of basin subsidence and the relative increasing rise in sea level are represented by the shales and clay-rich limestone of the La Peña Formation [21] [24], a geological formation which represents the maximum level of sea flooding that extended over the entire Sabinas Basin and the Tamaulipas block.

The deposition of basinal micritic limestones and shales began in the Albian age and continued until the Cenomanian. An extensive carbonate platform, in which carbonates and evaporites were deposited, prevailed during this period. These rock types are represented by the Aurora and Kiamichi Formations, as well as the Washita Group (Georgetown, Del Río and Buda Formations).

The regressive and prograding sequences (Supersequence 3; Cycle V), represented by the Eagle Ford, Austin, San Miguel, Olmos and Escondido Formations, originated during the late Cretaceous. The Eagle Ford Formation consists of black shales rhythmically interbedded with clayey limestone and sandstone cemented with carbonate, while the Austin Formation is composed of interbedded calcareous shales and light gray argillaceous limestone. Both geological formations present similar facie changes, which indicate a similar environmental deposition. The higher calcium carbonate content in the Austin Formation is the main difference between the two formations and is linked to climate change and/or the decrease in platform depth during the prograde cycle, which developed at a high eustatic level [1].

\section{Material and Methods}

This study of the $\kappa$ and NGR found in the carbonate sedimentary rocks of the Sabinas Basin was carried out in four stages. In the first stage, the fieldwork was planned selecting 16 outcrops for measurements of both physical properties and the sampling of the studied rocks. Such carbonate rocks (limestones) studied belong to several geological formations deposited during the Cretaceous Period [5]. The Taraises, Cupido, La Peña, Aurora and Kiamichi Formations belong to 
early Cretaceous, whereas the Washita Group and Eagle Ford and Austin Formations were deposited during the late Cretaceous (Figure 2).

In the second stage, both physical properties were measured at various outcrops of these rocks. In each of these outcrops, only one of the geological formations studied is shown, in which the measurements were taken in several points dispersed by the outcrop (Figure 3). Initially, at the selected measurement points 5 measurements of $\kappa$ were performed using a KT-Plus made by Terraplus Inc., after which one NGR measurement was taken using an RS-125 super gamma ray Spectrometer made by Radiation Solutions Inc., which has 4 channels: total gamma radiation (TGR in $\mu \mathrm{R} / \mathrm{h}$ ); potassium concentration ( $\mathrm{K}$ in \%); uranium concentration ( $\mathrm{U}$ in $\mathrm{ppm}$ ); and, thorium concentration (Th in $\mathrm{ppm}$ ). The measurements of NGR were performed for 120 seconds at each point, with a total of 153 samples taken at each of the sites. The KT-10 Plus and gamma ray Spectrometer were placed directly on the rock, on a flat surface. The area measured with the KT-10 Plus is approximately $7 \mathrm{~cm}^{2}$, according to the diameter of the console. The spectrometer measures an approximate space of $30 \times 30 \times 30$ $\mathrm{cm}$. In this second stage samples are also taken in the outcrops.

During the second stage, the samples were prepared in order to both measure the physical properties and perform the petrographic analysis (analysis of thin sections), while the third stage comprised the statistical processing of the data obtained for both physical properties (range, average and standard deviation) in each of the geological formations. In the final stage, all information obtained from the research (physical properties, field descriptions and petrography) was interpreted.

Although the research was carried out in outcrops in which no contacts between geological formations are observed (only a geological formation is showed) in this last stage, a virtual record of the cross-sectional measurement of the limestone sequence was also undertaken, taking the average $\kappa$ and NGR values for each geological formation measures in different outcrops and considering their stratigraphic positions (see the stratigraphic column in Figure 2). The constructed stratigraphic column allows using the both physical properties to compare geological formations deposited in different geological time. Initially, an analysis of the possible impurities in limestones of these geological formations is carried out, according to the values of magnetic susceptibility and NGR. Later possible
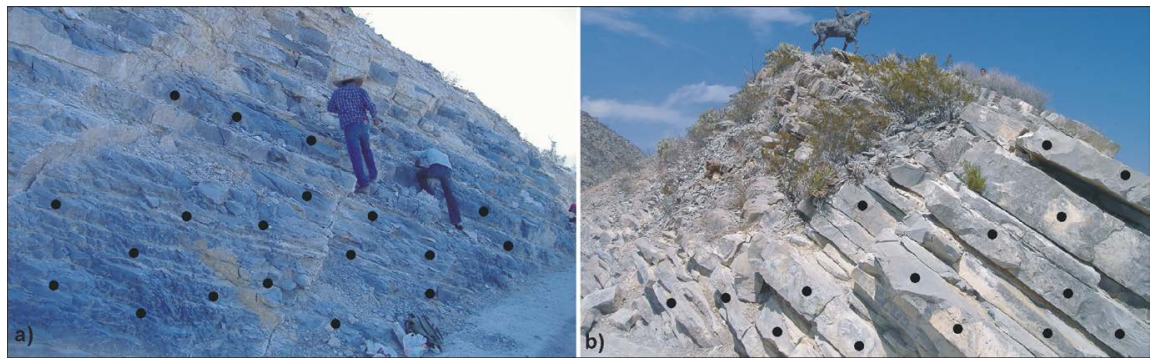

Figure 3. Outcrops of carbonated rocks. (a) Aurora Fm; (b) Washita Group. Filled black circles indicate measurements points in the outcrops. 
relationships with the sedimentation conditions of these rocks are suggested.

\section{Results}

In the geological formations studied here, the limestones differ in terms of their $\kappa$ and NGR values, with the highest $\kappa$ values recorded in the Washita Group and the Taraise Fm., while the Austin and Aurora Formations recorded the lowest values (Table 1). The limestones of the Washita Group and the Taraise Fm. have the highest values of $\kappa$.

The highest NGR values (total gamma radiation) were recorded in the Washita Group, as well as in the Cupido, La Peña and Eagle Ford formations, with the lowest values recorded in the Austin, Aurora and Taraise formations (Table 2). These values are related to Th concentrations.

Table 1. Descriptive statistics of the $\kappa \times 10^{-3}$ SI in limestones of some Cretaceous formations of the Sabinas basin. N: number of outcrops and samples; SD: standard deviation; $\mathrm{O}$ $+\mathrm{S}$ : total of outcrops and samples. Av.: Average.

\begin{tabular}{|c|c|c|c|c|c|c|c|}
\hline \multicolumn{4}{|c|}{ Austin Fm. } & \multicolumn{4}{|c|}{ Eagle Ford Fm. } \\
\hline Measurements & Range & Av. & SD & Measurements & Range & Av. & SD \\
\hline Outcrops. $N=64$ & $0.005-0.025$ & 0.01 & 0.005 & Outcrops. $\mathrm{N}=64$ & $0.009-0.06$ & 0.03 & 0.01 \\
\hline Samples. $\mathrm{N}=9$ & $0.004-0.023$ & 0.01 & 0.005 & Samples. $N=10$ & $0.009-0.05$ & 0.02 & 0.01 \\
\hline $\mathrm{O}+\mathrm{S}$ & $0.004-0.025$ & 0.01 & 0.006 & $\mathrm{O}+\mathrm{S}$ & $0.009-0.06$ & 0.03 & 0.02 \\
\hline \multicolumn{4}{|c|}{ Washita Group } & \multicolumn{4}{|c|}{ Kiamichi Fm. } \\
\hline Outcrops. $\mathrm{N}=272$ & $0.01-0.26$ & 0.09 & 0.06 & Outcrops. $\mathrm{N}=85$ & $0.007-0.04$ & 0.025 & 0.009 \\
\hline Samples. $\mathrm{N}=37$ & $0.01-0.024$ & 0.08 & 0.04 & Samples. $\mathrm{N}=11$ & $0.005-0.03$ & 0.024 & 0.007 \\
\hline $\mathrm{O}+\mathrm{S}$ & $0.01-0.26$ & 0.09 & 0.07 & $\mathrm{O}+\mathrm{S}$ & $0.005-0.07$ & 0.025 & 0.009 \\
\hline \multicolumn{4}{|c|}{ Aurora Fm. } & \multicolumn{4}{|c|}{ La Peña Fm. } \\
\hline Outcrops. $\mathrm{N}=354$ & $0.001-0.13$ & 0.01 & 0.02 & Outcrops. $\mathrm{N}=62$ & $0.004-0.06$ & 0.02 & 0.008 \\
\hline Samples. $N=29$ & $0.001-0.11$ & 0.01 & 0.01 & Samples. $\mathrm{N}=15$ & $0.002-0.05$ & 0.01 & 0.007 \\
\hline $\mathrm{O}+\mathrm{S}$ & $0.001-0.11$ & 0.01 & 0.02 & $\mathrm{O}+\mathrm{S}$ & $0.002-0.06$ & 0.02 & 0.008 \\
\hline \multicolumn{4}{|c|}{ Cupido Fm. } & \multicolumn{4}{|c|}{ Taraise Fm. } \\
\hline Outcrops. $\mathrm{N}=297$ & $0.001-0.16$ & 0.02 & 0.03 & Outcrops. $\mathrm{N}=51$ & $0.06-0.15$ & 0.09 & 0.04 \\
\hline Samples. $\mathrm{N}=25$ & $0.001-0.014$ & 0.02 & 0.01 & Samples. $N=17$ & $0.04-0.12$ & 0.08 & 0.02 \\
\hline $\mathrm{O}+\mathrm{S}$ & $0.001-0.16$ & 0.02 & 0.02 & $\mathrm{O}+\mathrm{S}$ & $0.04-0.15$ & 0.09 & 0.03 \\
\hline
\end{tabular}

Generally, the limestones of the Lower Cretaceous present a decline in $\kappa$ and NGR from the lowest to the highest levels of the stratigraphic sequence (Figure 4), behavior which is also observed in the Upper Cretaceous limestones. In the lower parts of both Cretaceous epochs, the limestone has high $\kappa$ values.

The limestones of the Taraise Formation, located in the lower part of the Lower Cretaceous in Figure 4, present the highest $\kappa$ values. These rocks have low total gamma radiation values due to their low concentrations of Th and $\mathrm{K}$ 
Table 2. Descriptive statistics of the NGR in outcrops of some Cretaceous limestones of the Sabinas basin. M: measurement.

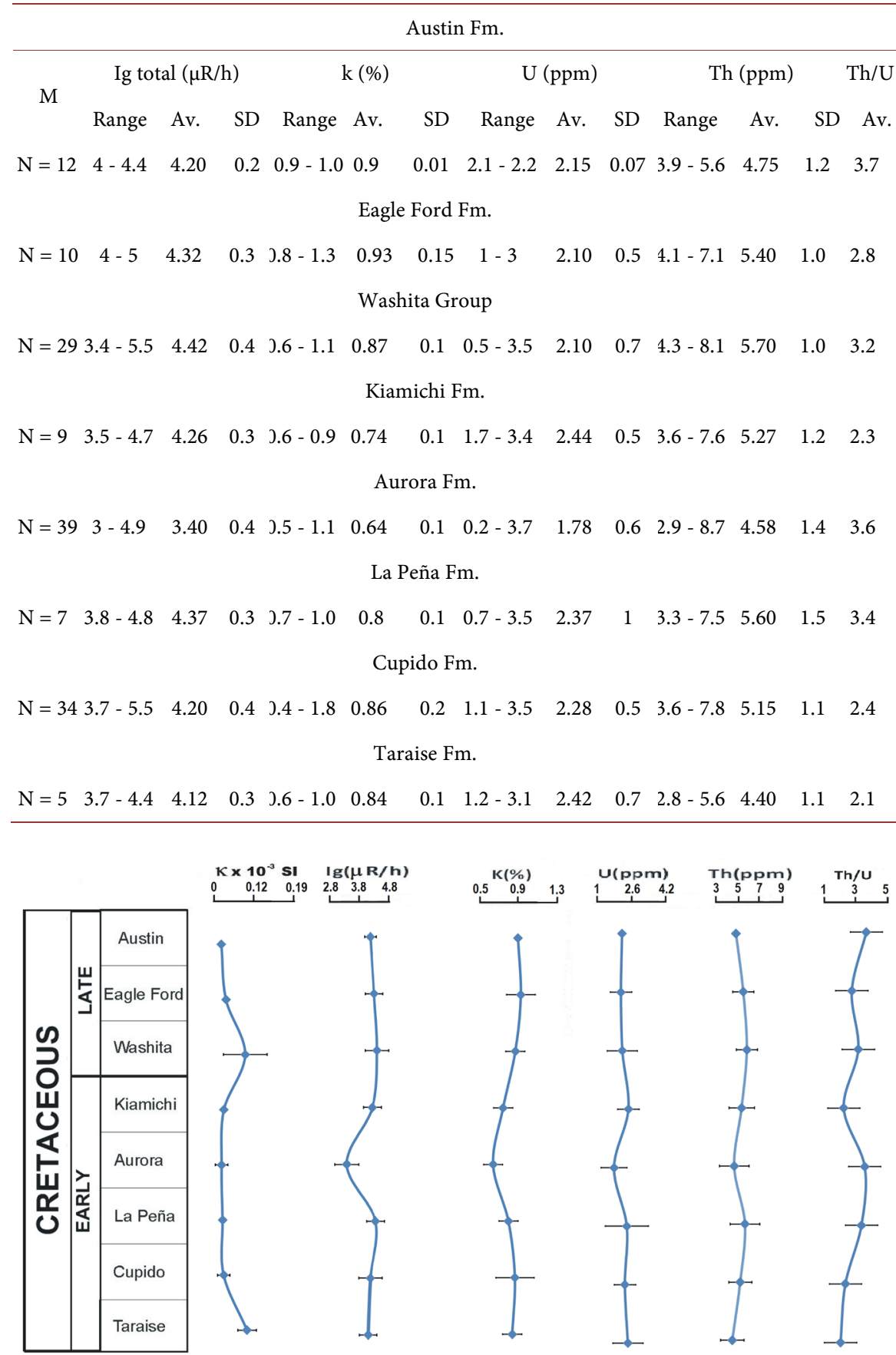

Figure 4. Variations of $\kappa$ and NGR in the Cretaceous limestone sequences of the Sabinas Basin. Average values of $\kappa$ and NGR for each geological formation are shown. Clastic sequence in the geological formation presented is not considered. Horizontal lines in the points indicate the uncertainty of the standard deviations. Chart is not scaled on the vertical. In the same are not considered the thickness of the geological formations.

and slightly higher concentrations of $U$.

The Cupido Formation was deposited above these limestones, as characterized 
by a marked decrease in $\kappa$ and an increase in NGR, with the latter depending on the Th and $\mathrm{K}$ concentrations.

The La Peña, Aurora and Kiamichi Formations overlay the Cupido Formation, occupying the middle and upper part of the Early Cretaceous. The three former geological formations are characterized by very low $\kappa$ values. The La Peña Formation presents a slight decrease in $\kappa$ and total gamma radiation (TGR) in the underlying limestones. In this geological formation, the $\mathrm{K}$ concentration decreases, whereas the Th and $U$ concentrations increase. The limestones of the Aurora Formation were deposited above the La Peña Formation, rocks which have lower $\kappa$ and NGR values.

The analyzed levels of limestones belong to the Early Cretaceous, which ended with the deposition of the limestone of the Kiamichi Formation in which the $\kappa$ and NGR values were higher.

The Late Cretaceous begins with the limestones of the Washita Group, which show an abrupt increase in the $\kappa$ and NGR values, with the latter due to the K and Th concentrations. In the limestones of the Eagle Ford Formation, deposited above the Washita Group, the $\kappa$ and NGR values (U and Th concentrations) decrease.

The highest level of the geological section analyzed terminates with limestones of the Austin Formation, in which the lowest values of $\kappa$ are recorded, as well as a greater decrease in NGR, which is linked to Th and $\mathrm{K}$ concentrations.

\section{Discussions}

\section{1. $\kappa$ and NGR as Indirect Indicators of Impurities in Cretaceous Limestones Located in the Sabinas Basin}

The highest NGR values related to Th concentrations in the limestones of Washita Group and the Cupido, La Peña and Eagle Ford formations, suggesting more siliciclastic impurities [11] [13]. The highest $\kappa$ values recorded in the Washita Group and the Taraise Fm. indicates that the limestones of the Washita Group and the Taraise Fm. have the highest contents of paramagnetic minerals or at least medium to low ferromagnetic mineral content [9]. Considering the typical composition of sedimentary rocks [14] and the results of petrographic analyzes in this research (Figure 5 and Figure 6) and previous ones [25], these minerals could be mainly iron oxides and hydroxides (e.g. magnetite, ilmenite, hematite and goethite) and iron sulphides (e.g. pyrite and chalcopyrite). The descriptions of the outcrops and the analysis of the thin section indicate some of the above mentioned minerals in the rocks studied in this research (Figure 5 and Figure 6). Other research in this region also reports these magnetic minerals on carbonate rocks [25]. These minerals were probably formed during the enrichment of organic matter that occurs in most of the limestones in the region [1] [5]. The accumulation of organic matter could generate iron sulphides, such as pyrite [26], a mineral which could subsequently undergo an oxidation process and generate iron oxides, such as magnetite [13]. Some limestones of the region 


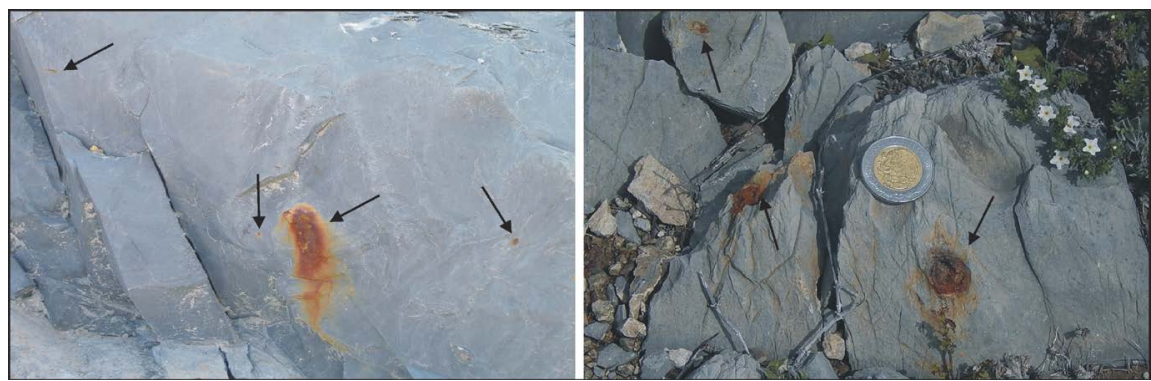

Figure 5. Outcrops of limestone in the Washita Group. The arrows indicate nodules of iron oxides.

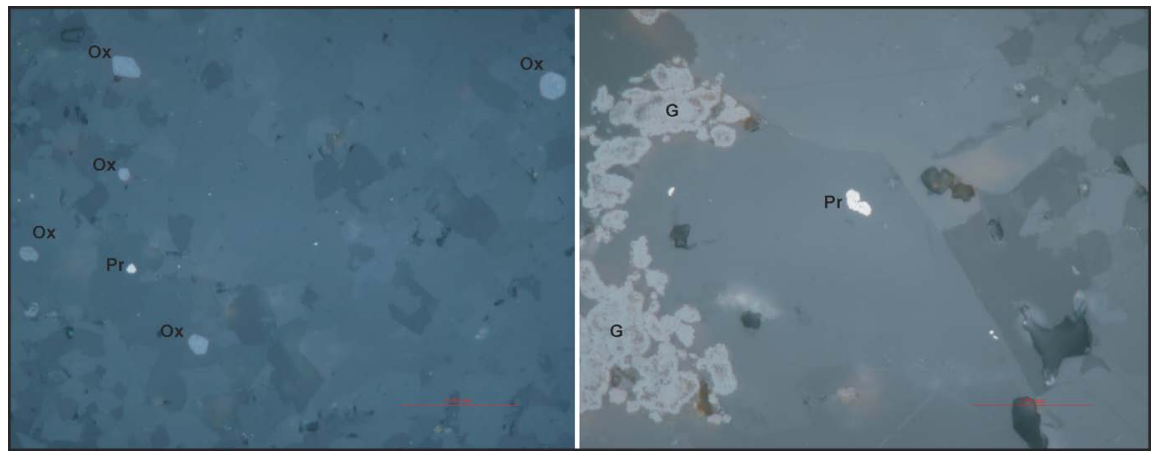

Figure 6. Thin section of a sample of limestone belonging to the Cupido Formation. Microphotographs taken with reflected light and without an analyzer. Ox: iron oxides (gray color); Pr: pyrite; and, G: transformation of iron oxides to goethite.

do present iron nodules (Figure 5), thus indicating the process described.

In the Taraise Formation the low concentrations of Th and $\mathrm{K}$ and slightly higher concentrations of $U$ (Figure 4) can be characteristics of limestone gray and a non-clayey. According to [21], limestones with this characteristics belonging to the lower level of this geological formation. In this case, the high values of $\kappa$ and the high concentrations of $U$ probably linked to the iron sulfides and organic matter, respectively. Previous studies report both components in these rocks [25]. It is likely that these minerals were acquired during the accumulation of organic matter. The decrease in $\mathrm{U}$ concentrations and $\kappa$ in the $\mathrm{Cu}$ pido Formation deposited above the Taraise Formation indicates that, in these limestones, $\kappa$ remains linked to the processes for the enrichment of organic matter, during which authigenic pyrite was formed. Both groups of physical properties suggest less pure limestones, that is, ones with higher clay content (detritus-rich limestones) and less organic matter at this stratigraphic level (Cupido Fm.).

A probable relationship between $\kappa$ and the $\mathrm{K}$ concentration is observed in the La Peña Formation possibly linked to iron-rich and $\mathrm{K}$ silicates such as biotite. Increases in $\mathrm{U}$ and $\mathrm{Th}$ concentrations suggest clay with a low $\mathrm{K}$ content, such as kaolinite and montmorrillonite. The limestones of the Aurora Formation deposited above the La Peña Formation, have lower $\kappa$ values, as well as lower U and Th concentrations indicating decreases in detrital content. 
In the Kiamichi Formation, the NGR is linked to the concentrations of $U$ and a decrease in both $\mathrm{Th}$ and $\mathrm{K}$ concentrations. This result suggests a large increase in organic matter and a decrease in detritus.

In the Washita Group, the abrupt increase in the $\kappa$ and the $\mathrm{K}$ and Th concentrations, as well as the decrease in $U$ concentrations, indicate a probable decrease in organic matter, and suggest that $\kappa$ is related to the siliciclastic content of the rock.

In the limestones of the Eagle Ford Formation the decrease of the $\kappa$ values and $\mathrm{U}$ and $\mathrm{Th}$ concentrations, as well as the small increase in $\mathrm{K}$ concentrations reveal a decrease in clay content, as well as increases in nonferrous silicates rich in potassium (e.g. feldspars and muscovite).

The lowest values of $\kappa$ recorded in the Austin Formation, as well as the decrease in the Th and $\mathrm{K}$ concentrations suggests a decrease in the siliciclastic content of these limestones compared to the lower stratigraphic levels of Late Cretaceous. The slight increase in $U$ concentrations indicates a rise in the organic matter content of these limestones, which is higher than in the limestone of the Eagle Ford Formation.

The Th concentration is an indicator of detrital material in limestone [17] and the $U$ concentration indicates enrichment in organic matter [18]. Based on the foregoing, it is possible to use the $\mathrm{Th} / \mathrm{U}$ ratio to ascertain the prevalence of increases in detrital material compared to organic matter in the lower levels of limestones in the Early Cretaceous (Aurora Formation). At the end of Early Cretaceous, the Kiamichi Formation changes the relationship pattern and reveals the accumulation of organic matter. The Late Cretaceous begins with a predominance of the accumulation of detrital material in the Washita Group. Later in the Eagle Ford Formation, the accumulation of organic matter predominates, a trend which is greatly reduced during the deposition of the Austin Formation.

Generally, in the Early Cretaceous, the $\kappa$ values in the limestones are mainly related to the $U$ concentrations and, therefore, to the content of organic matter, whereas, in the Late Cretaceous, the $\kappa$ values are linked to detrital material, thus indicating the nature and characteristic of the geological formations studied here.

\subsection{Possible Relationships of $\kappa$ and NGR with Changes in the Sedimentation Conditions at Different Levels of Cretaceous Limestone in the Sabinas Basin}

From the description and analysis of the $\kappa$ and NGR behavior of Cretaceous limestones, it is possible to create a reconstruction of the formation environment of the levels of Cretaceous limestones studied here (Figure 4). Both physical properties suggest that some levels of the Taraise Formation (Early Cretaceous) were deposited in a moderately deep basin environment, dominated by precipitation of $\mathrm{CaCO}_{3}$ as well as the accumulation and transformation of organic matter. Authigenic pyrites are generated during this process, which, themselves, 
once oxidized, generate iron oxides and hydroxides, some of which are slightly magnetic. Subsequently, a marine transgression occurred [27], causing a rise in sea levels. During this period, the limestones of the Cupido Formation were deposited in a prograding depositional environment with rising sea levels [1]. This environment enabled a high level of $\mathrm{CaCO}_{3}$ production, less accumulation of organic matter and a greater amount of detritus.

Another marine transgression occurred in the mid-Early Cretaceous [1] [21] [24], generating a sea level rise and, thus, conditions for increased detritus in the limestones of the La Peña Formation. The sea level subsequently decreased in the basin, with less detritus deposited in the limestone of the Aurora Formation. Subsequently, limestones with a greater amount of organic matter and less detritus were deposited (the Kiamichi Formation).

At the beginning of the Late Cretaceous (Cenomanian-Santonian), the basin depth decreased further, leading to the deposition of a limestone sequence with little organic matter and a large amount of detritus. Both components in this rock decreased as the period progressed. The decrease in basin depth is associated with a strong uprising in either the same or a marine regression. This process caused an increase in the influx of terrigenous material into the basin, generating the limestone of the Washita Group. According to research carried out in other regions [11], high increases of $\kappa$ and NGR can indicate a low sea level in the basin. Subsequently, a slight subsidence began in the basin, causing the accumulation of a lower amount of terrigenous material, mainly comprising clay, and generating the limestones of the Eagle Ford Formation. This process continued, resulting in the deposition of greater amounts of pure limestone, forming the Austin Formation.

\section{Conclusions}

The analysis carried out in this study suggests that magnetic susceptibility and natural gamma radioactivity can be considered as indirect indicators of impurities in limestones and possibly the sedimentation environment during the deposition of the carbonated sedimentary rocks of the Sabinas Basin. The $\kappa$ and NGR values suggest slight differences in the degree of impurities and the mineralogical compositions of limestones deposited in this basin during the Cretaceous. These values also suggest variability in the deposition environments of these rocks. These environments determine different compositions of paramagnetic and ferromagnetic minerals in the limestones.

The reconstruction of the formation environment of the limestone sequence of the Lower and Upper Cretaceous corroborates the potential use of $\kappa$ and NGR as indirect indicators for the formation conditions of limestones, indicating the enrichment of organic matter and siliciclastic components. This finding indicates that it is possible to use these physical properties along a vertical section of a stratigraphic sequence to determine changes and conditions in the formation environment of the basin. 


\section{Acknowledgements}

The authors gratefully acknowledge the University of Coahuila for the support received, and thank the Department of Crystallography Mineralogy and Mineral Deposits at the University of Barcelona for providing access to the Optical Mineralogy Laboratory.

\section{References}

[1] Eguiluz de Antuñano, S. (2001) Geologic Evolution and Gas Resources of the Sabinas Basin in Northeastern Mexico. In: Bartolini, C., Buffler, R.T. and Cantú-Chapa, A., Eds., The Western Gulf of Mexico Basin: Tectonics, sedimentary basins, and Petroleum Systems, AAPG Memoir, 75, 241-270.

[2] Corona-Esquivel, R., Tritlla, J., Benavides-Muñoz, M.E., Piedad-Sánchez, N. and Ferrusquía-Villafranca, I. (2006) Geología, estructura y composición de los principales yacimientos de carbón mineral en México [Geology, Structure and Composition of the Main Coal Deposits in Mexico]. Boletin de la Sociedad Geológica Mexicana, 58, 141-160.

[3] García-Alonso, D., Canet, C., González-Partida, E., Villanueva-Estrada, R.E., Prol-Ledesma, R.M., Alfonso, P., Caballero-Martínez, J.A. and Lozano-SantaCruz, R. (2011) The Cretaceous Sediment-Hosted Copper Deposits of San Marcos (Coahuila, Northeastern Mexico): An Approach to Ore-Forming Processes. Journal of South American Earth Sciences, 31, 432-443. https://doi.org/10.1016/j.jsames.2011.02.012

[4] González-Sánchez, F., González-Partida, E., Canet, C., Atudorei, V., Alfonso, P., Morales-Puente, P., Cienfuegos-Alvarado, E. and González-Ruiz, L. (2015) Geological Setting and Genesis of Stratabound Barite Deposits at Múzquiz, Coahuila in Northeastern Mexico. Ore Geology Reviews, 81, 1184-1192.

https://doi.org/10.1016/j.oregeorev.2015.10.008

[5] González-Sánchez, F., Puente-Solís, R., González-Partida, E. and Camprubí, A. (2007) Estratigrafía del Noreste de México y su relación con los yacimientos estratoligados de fluorita, barita, celestina y $\mathrm{Zn}-\mathrm{Pb}$ [Stratigraphy of Northeastern Mexico and Its Relationship with Stratabound Fluorite, Barite, Celestine and $\mathrm{Zn}-\mathrm{Pb}$ Deposits]. Boletin de la Sociedad Geológica Mexicana, 59, 43-62.

[6] Pascacio-Toledo, R. (2001) Texto guía Carta magnética de Nueva Rosita G14-1 [Guide text of Nueva Rosita Magnetic Map G14-1]. Escala 1:250,000. 19 p.

[7] Adams, J.A.S. and Weaver, C.E. (1958) Thorium-to-Uranium Ratios as Indicators of Sedimentary Processes; Example of Concept of Geochemical Facies. American. Association of Petroleum Geologist Bulletin, 42, 387-430.

[8] Bábek, O., Kalvoda, J., Aretz, M., Cossey, P.J., Devuyst, F., Herbig, H. and Sevastopulo, G. (2010) The Correlation Potential of Magnetic Susceptibility and Outcrop Gamma-Ray Logs at Tournaisian-Viséan Boundary Sections in Western Europe. Geologica Belgica, 13, 291-308.

[9] Clark, D.A. (1997) Magnetic Petrophysics and Magnetic Petrology: Aids to Geological Interpretation of Magnetic Surveys. AGSO Journal of Australian Geology \& Geophysics, 7, 83-103.

[10] Da Silva, A., Potma, K., Weissenberger, J., Whalen, M., Humblet, M., Mabille, C. and Boulvain, F. (2009) Magnetic Susceptibility Evolution and Sedimentary Environments on Carbonate Platform Sediments and Atolls, Comparison of the Frasnian from Belgium and Alberta, Canada. Sedimentary Geology, 214, 3-18. 
https://doi.org/10.1016/j.sedgeo.2008.01.010

[11] Ellwood, B.B., Crick, R.E., El Hassani, A., Benoist, S.L. and Young, R.H. (2000) Magnetosusceptibility Event and Cyclostratigraphy Method Applied to Marine Rocks: Detrital Input versus Carbonate Productivity. Geology, 28, 1135-1138. https://doi.org/10.1130/0091-7613(2000)28<1135:MEACMA >2.0.CO;2

[12] Hatfield R.G. and Stoner J.S. (2013) Magnetic Proxies and Susceptibility. The Encyclopedia of Quaternary Science, 2, 884-898.

[13] Hladil, J., Gersl, M., Strnad, L., Frana, J., Langrova, A. and Spisiak, J. (2006) Stratigraphic Variation of Complex Impurities in Platform Limestones and Possible Significance of Atmospheric Dust: A Study with Emphasis on Gamma-Ray Spectrometry and Magnetic Susceptibility Outcrop Logging (Eifelian-Frasnian, Moravia, Czech Republic). International Journal Earth Sciences, 95, 703-723.

https://doi.org/10.1007/s00531-005-0052-8

[14] Boggs, S. (2009) Petrology of Sedimentary Rocks. 2nd Edition, Cambridge University Press, Cambridge, 600 p. https://doi.org/10.1017/CBO9780511626487

[15] Mittlefehldt, D.W. (1999) Potassium. In: Marshall, C.P. and Fairbridge, R.W., Eds., Encyclopedia of Geochemistry, Kluwer Academic Publishers, London, 712 p.

[16] Dickson, B.L. and Scott, K.M. (1997) Interpretation of Aerial Gamma Ray Surveys-Adding the Geochemical Factors. AGSO Journal of Australian Geology \& Geophysics, 17, 187-200.

[17] Doveton, J.H. and Merriam, D.F. (2004) Borehole Petrophysical Chemostratigraphy of Pennsylvanian Black Shales in the Kansas Subsurface. Chemical Geology, 3-2, 249-258. https://doi.org/10.1016/j.chemgeo.2003.12.027

[18] Lüning, S., Wendt, J., Belka, Z. and Kaufmann, B. (2004) Temporal-Spatial Reconstruction of the Early Frasnian (Late Devonian) Anoxia in NW Africa; New Field Data from the Ahnet Basin (Algeria). Sedimentary Geology, 163, 237-264. https://doi.org/10.1016/S0037-0738(03)00210-0

[19] Chávez-Cabello, G., Aranda-Gómez, J.J., Molina-Garza, R.S., Cossío-Torres, T., Arvizu-Gutiérrez, I.R. and González-Naranjo, G.A. (2005) La falla San Marcos: una estructura jurásica de basamento multirreactivada del noreste de México. [The San Marcos Fault: A Jurassic Structure of Multireactived Basement in Northeastern Mexico]. Boletin de la Sociedad Geológica Mexicana, 57, 27-52.

[20] Goldhammer, R.K., Lehmann, P.J., Todd, R.G., Wilson, J.L., Ward, W.C. and Johnson, C.R. (1991) Sequence Stratigraphy and Cyclostratigraphy of the Mesozoic of Sierra Madre Oriental, Northeast Mexico. A Field Guide Book: Gulf Coast Section, Society of Economic Paleontologists and Mineralogists, Tulsa, 85 p.

[21] Imlay, W.R. (1936) Geology of the Western Part of the Sierra de Parras. Bulletin of the Geological Society of America, 47, 1091-1152. https://doi.org/10.1130/GSAB-47-1091

[22] Murillo-Muñeton, G. (1999) Stratigraphic Architecture, Platform Evolution, and Mud-Mound Development in the Lower Cupido Formation (Lower Cretaceous), Northeastern Mexico. Ph.D. Dissertation, Texas A\&M University, College Station.

[23] Wilson, J.L. and Pialli, G. (1977) A Lower Cretaceous Shelf Margin in Northern Mexico. In: Cretaceous Carbonates of Texas and Mexico: Applications to Subsurface Exploration, The University of Texas at Austin, Bureau of Economic Geology, Report of Investigations, 89, 286-298.

[24] Humphrey, W.E. (1949) Geology of Sierra de Los Muertos Area, Mexico (with Descriptions of Aptian Cephalopods from the La Peña Formation). Bulletin of the 
Geological Society of America, 60, 89-176. https://doi.org/10.1130/0016-7606(1949)60[89:GOTSDL]2.0.CO;2

[25] Batista-Rodríguez, J., Proenza-Fernández, J., Rodríguez-Vega, A., López-Saucedo, F. and Cázares-Carreón, K. (2017) Magnetic Susceptibility and Natural Gamma Radioactivity as Indirect Proxies for Characterization of Sandstones and Limestones of the Sabinas Basin. Geofizika, 34, 19-43. https://doi.org/10.15233/gfz.2017.34.6

[26] Merinero, R., Lunar, R. and Martínez, J. (2010) Carbonatos metanógenos y pirita framboidal autigénica: geomarcadores de la actividad de organismos quimiosintéticos en el golfo de Cádiz. [Methanogenic Carbonates and Autigenic Pyrite Framboid: Geomarkers of the Activity of Chemosynthetic Organisms in the Gulf of Cadiz]. Macla, 12, 29-37.

[27] Lehmann, C., Osleger, D.A., Montañez, D.A., Sliter, I.P., Arnaud-Vanneau, A. and Banner, J. (1999) Evolution of Cupido and Coahuila Carbonate Platforms, Early Cretaceous, Northeastern Mexico. Bulletin of the Geological Society of America, $111,1010-1029$.

https://doi.org/10.1130/0016-7606(1999)111<1010:EOCACC >2.3.CO;2 